\title{
2011年東北地方太平洋沖地震における 漁港海岸保全施設の被災状況
}

\author{
浅川 典敬 1 -中村 隆 $^{2} \cdot$ 加藤 広之 $^{3} \cdot$ 早川 光 ${ }^{4}$ 佐藤 勝弘 $^{5} \cdot$ \\ 見上 敏文 6 - 小玉 篤 $7 \cdot$ 鈴木 彰 8 \\ 1正会員＼cjkstart水産庁漁港漁場整備部防災漁村課（干101-8907 東京都千代田区霞ヶ関1-2-1） \\ E-mail: noritaka_asakawa@nm.maff.go.jp \\ 2一般財団法人漁港漁場漁村総合研究所 第1調査研究部（テ101-0032 東京都千代田区岩本町3-4-6） \\ E-mail: nakamura@jific.or.jp \\ 3 正会員 一般財団法人漁港漁場漁村総合研究所 第1調査研究部（†101-0032 東京都千代田区岩本町3-4-6） \\ E-mail: katou@jific.or.jp \\ 4一般財団法人漁港漁場漁村総合研究所 第1調查研究部（产101-0032 東京都千代田区岩本町3-4-6） \\ E-mail: hayakawa@jific.or.jp \\ 5正会員＼cjkstart株式会社アルファ水エコンサルタンツ＼cjkstart東京本部（†101-0031 東京都千代田区東神田2-7） \\ E-mail: k-sato@ahec.jp \\ 6正会員 株式会社アルファ水工コンサルタンツ 技術部（广063-0829 札幌市西区発寒9条14丁目） \\ E-mail: mikami@ahec.jp \\ 7 株式会社アルファ水工コンサルタンツ 技術部（（０63-0829 札幌市西区発寒9条14丁目） \\ E-mail: kodama@ahec.jp \\ 8 国際気象海洋株式会社 第3技術部（T135-0001 東京都江東区毛利1-18-8） \\ E-mail: chibiru3@imoc.co.jp
}

2011年3月11日に発生した東北地方太平洋沖地震による津波は，東北地方の沿岸域に甚大な被害をもた らし, 堤防, 護岸, 胸壁等の海岸保全施設も多くの被災が生じた. 今回の漁港海岸施設の被災では, これ までの設計条件を超える外力が作用したものと想定されたことから，被災状況の調査とその外力の解析， さらに復旧事業を実施するにあたっての設計条件の見直し等の考え方を検討・整理した. 本報では, 水産 庁「平成23年度海岸保全施設設計条件等緊急調査」の結果より, 漁港海岸施設の被災状況, 被災パターン について整理し，胸壁は堤防，護岸に比べ被災時に全壊割合が高い，押し波と引き波による被災割合は， 堤防では同程度, 護岸では引き波, 胸壁では押し波による割合が高い, 津波越流深が大きくなるに伴い被 災率が一度減少し, 再び高くなる等の知見を得た。

Key Words :Tohoku Earthquake Tsunami, tsunami survey, damage factors, tsunami force, shore protection facilities

\section{1. はじめに}

2011年3月11日に発生した東北地方太平洋沖地震によ る津波は，東北地方の沿岸域に甚大な被害をもたらし， 防潮堤，護岸，胸壁等の海岸保全施設も多くの施設に損 壊・消失等の被災が生じた。今回の漁港海岸施設の被災 については，これまでの設計条件を超える外力が作用し たものと想定されたこと等から，水産庁では「平成23年 度海岸保全施設設計条件等緊急調査」を実施し，被災状 況の調査とその外力の解析, さらに復旧事業を実施する にあたっての設計条件の見直し等の考え方の検討・整理 を行った.
同調査では，施設の被害状況等を施設管理者の被災報 告や航空写真等を整理することにより把握し，施設工種 別の被災概要や周辺地形等を整理した. さらに現地踏査 の実施による詳細な被災状況結果を踏まえ, 数值シミュ レーション, 水理模型実験, および数值流体解析モデル 計算等の実施によって，被災メカニズム・外力等を推定 し，津波を考慮した漁港海岸保全施設の設計条件の見直 しに関する検討を行った. 図-1に同調査のフローを示す. 本研究では同調査の結果を整理するとともに，岩手県， 宮城県, 福島県での漁港海岸保全施設（堤防・護岸・胸 壁）の被災状況と被災パターンについて分析し, 被災メ カニズムについての考察を行った. 


\section{2. 調査手法}

\section{(1) 既往資料の収集・整理}

岩手県，宮城県，福島県での漁港海岸保全施設の被災 状況を把握するため，(1)漁港台帳，(2海岸保全施設台帳， (3)漁港海岸平面図，(4)被災報告資料（県/市町村)，(5)航 空写真・衛星画像（被災前・被災後），(6)津波痕跡高調 查結果（東北地方太平洋沖地震津波合同調查グループ調 查 $\left.^{1)}\right)$ ，(7)現地調査結果等の資料を収集し，漁港または 漁港海岸保全施設別の分類・整理およびGISを用いた空 間的な被災状況の可視化等を行った。

\section{（2）概略調査（被災状況確認調査）}

岩手県，宮城県，福島県の全漁港260港のうち海岸保 全施設を有する143漁港を対象として，表-1に示す海岸 保全施設の被災状況分類に基づき，施設ごとの被災箇所， 被災延長，被災状況について，航空写真・衛星画像と既 存資料（海岸保全施設台帳，被災報告資料）を用いて整 理した。

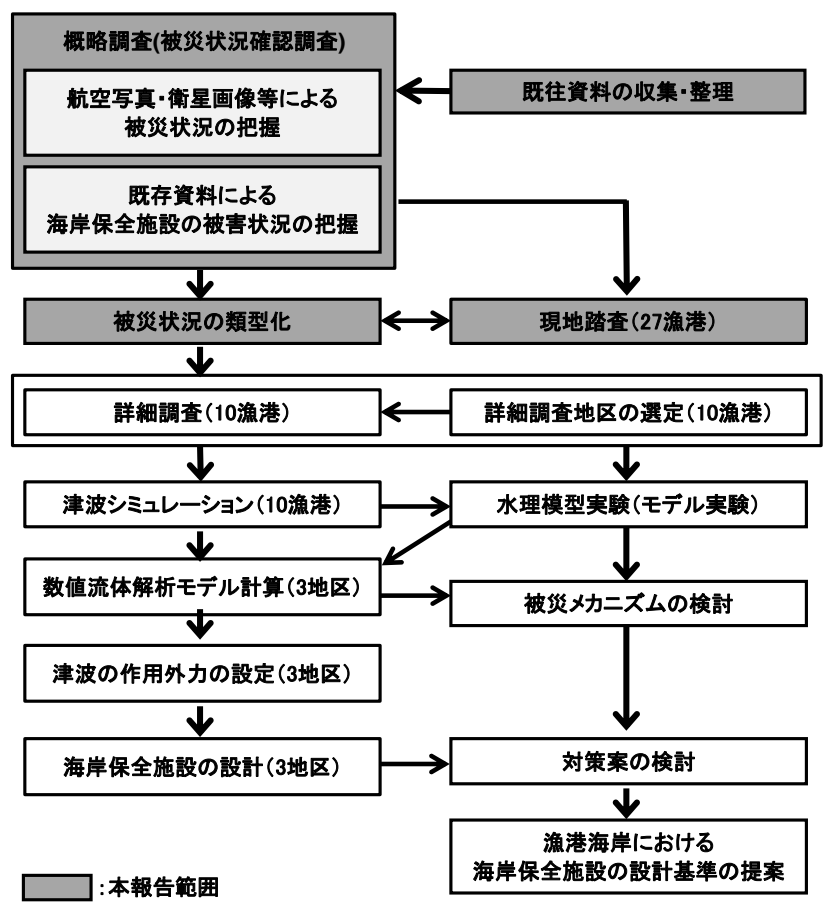

図-1「平成23年度海岸保全施設設計条件等緊急調査」の フロー

表-1＼cjkstart海岸保全施設の被災状況分類

\begin{tabular}{|c|l|}
\hline 全壊 & $\begin{array}{l}\text { 施設機能がほぼ全て失われた状態 } \\
\text { (堤体全体の倒壊、盛土・被覆工の全流出 } \\
\text { など) }\end{array}$ \\
\hline 半壊 & $\begin{array}{l}\text { 施設機能の一部が失われた状態 } \\
\text { (堤体の移動、傾倒、部分破損、被覆工の } \\
\text { 部分流出、基礎工の洗掘など })\end{array}$ \\
\hline 被災無し & 上記以外 \\
*沈下のみの場合は被災無しに分類
\end{tabular}

なお，沈下については，被災報告資料において被災状 況として沈下と記載されているものが多数あったが，施 設位置での局所沈下であるか、または地殼変動による広 域沈下であるかの判定が出来なかったことから，ここで は被災無しとして分類・整理した。

\section{(3) 現地踏査}

海岸保全施設の種別、被災規模、被災形態等を考慮し て選定した岩手県13漁港，宮城県11漁港，福島県3漁港 の計27漁港を対象として海岸保全施設および背後地の被 災状況について現地踏査を実施した．表-2に現地踏査実 施漁港一覧を示寸。

\section{(4) 被災形態の類型化}

概略調查および現地踏查の結果をもとに海岸保全施設 の被災形態のパターン化を行った.

なお，被災形態のパターン化について対象とした海岸 保全施設の工種は堤防，護岸，胸壁である。図-2に堤 防・護岸・胸壁の構造図を示す。

\section{3. 被災状況の概要}

被災概要として，概略調查の結果をもとに整理した岩

\section{表-2＼cjkstart現地踏査実施漁港一覧}

\begin{tabular}{|c|c|c|c|c|c|}
\hline 県 & 漁港名 & 市町村 & $\begin{array}{l}\text { 管理者 } \\
\text { （種別） }\end{array}$ & 被害規模 & $\begin{array}{c}\text { 津波高 } \\
\text { (既存施設高) } \\
\text { T.P.m }\end{array}$ \\
\hline \multirow[t]{13}{*}{ 岩手 } & 種市 & 洋野町 & 県(2) & 中 & $9.0(12.0)$ \\
\hline & 久喜 & 久慈市 & 県(2) & 中 & $15.0(12.0)$ \\
\hline & 太田名部 & 普代村 & 県(2) & 小 & - \\
\hline & 茂師 & 岩泉町 & 町(1) & 中 & $22.4(10.3)$ \\
\hline & 田老 & 宮古市 & 県(2) & 中 & $16.3(10.0)$ \\
\hline & 宿 & 宮古市 & 市(1) & 不明 & $23.0(11.0)$ \\
\hline & 山田 & 山田町 & 県(3) & 大 & $10.9(4.0)$ \\
\hline & 吉里吉里 & 大槌町 & 県(2) & 不明 & $19.0(6.3)$ \\
\hline & 箱崎 & 釜石市 & 県(2) & 不明 & $19.4(5.6)$ \\
\hline & 両石 & 釜石市 & 県(2) & 大 & $21.2(9.3)$ \\
\hline & 越喜来 & 大船渡市 & 県(2) & 中 & 18.3(7.9) \\
\hline & 野野前 & 大船渡市 & 市(1) & 中 & 24.3(7.9) \\
\hline & 六ヶ浦 & 陸前高田市 & 市(1) & 不明 & $14.0(8.5)$ \\
\hline \multirow[t]{11}{*}{ 宮城 } & 只越 & 気仙沼市 & 市(1) & 中 & 15.0 \\
\hline & 気仙沼 & 気仙沼市 & 県(特3) & 大 & $10.5(3.1)$ \\
\hline & 川原 & 気仙沼市 & 市(1) & 中 & $10.0(3.1)$ \\
\hline & 伊里前 & 南三陸町 & 県(2) & 大 & $12.7(4.6)$ \\
\hline & 寄木 & 南三陸町 & 町(1) & 大 & 13.1 \\
\hline & 志津川 & 南三陸町 & 県(2) & 大 & $15.8(4.6)$ \\
\hline & 波伝谷 & 南三陸町 & 県(2) & 大 & 20 \\
\hline & 雄勝 & 石巻市 & 県(2) & 大 & $16.2(4.1)$ \\
\hline & 御前 & 女川町 & 町(1) & 大 & 9.4 \\
\hline & 桃ノ浦 & 石巻市 & 県(2) & 中 & 10.2(4.6) \\
\hline & 荒浜 & 亘理町 & 県(2) & 大 & $11.4(6.2)$ \\
\hline \multirow[t]{3}{*}{ 福島 } & 釣師浜 & 新地町 & 県(2) & 大 & $12.0(6.2)$ \\
\hline & 松川浦 & 相馬市 & 県(3) & 大 & $12.0(6.2)$ \\
\hline & 豊間 & いわき市 & 県(2) & 中 & $8.5(6.2)$ \\
\hline
\end{tabular}


手県，宮城県，福島県での海岸保全施設の工種別（堤 防・護岸・胸壁）の施設数，施設延長，被災延長，被災 延長比を表-3に示す，施設延長は海岸保全施設台帳をも とに整理し，現地調査結果等を踏まえ補正を行った。被 災延長は管理者の被災報告資料から整理し，現地調査結 果，衛星写真等を踏まえ補正を行った。なお，胸壁は福 島県には存在していなかった。

各工種の全延長に対する被災施設（全壊，半壊）の延 長は，堤防が28,094 m に対し 15,657 m(56\%), 護岸が 44,355 m に対し18,679 m(42\%), 胸壁が26,963 mに対し 4,613 m(17\%)であった。 なお，胸壁は堤防，護岸と異な り被災延長のほとんどが全壊となっている.

これは，堤防，護岸が波返工・被覆工等の複合的な構 造のため, 部分的な破壊によって半壊と判定されるのに 対し，胸壁は主として本体工の被災で全壊と判定される
ためと推察される.

\section{4. 被災パターンの分類}

現地踏査の結果, 海岸保全施設の被災パターンとして は，押し波，引き波および洗掘の有無で大別できると判 断されたことから，図-3に示す工種別の被災パターンの 設定を行い，表-4に示す被災パターン判定条件から各被 災施設の被災パターンの分類を行った。

なお，被災報告資料から被災パターン判定ができる場 合はそれを使用し，判定できない場合は現地調査写真， 航空写真・衛星画像等から分類・整理した.また，複数 の被災パターンが混在する被災施設，施設の流失等によ り被災パターンが不明な被災施設も一部存在している.

表-3 施設工種別被災概要（施設数，施設延長，被災延長，被災延長比）

\begin{tabular}{|c|c|c|c|c|c|c|c|c|c|}
\hline & & \multirow{3}{*}{ 施設数 } & \multirow{3}{*}{ 施設延長(m) } & \multicolumn{6}{|c|}{ 被災延長 } \\
\hline & & & & \multicolumn{2}{|c|}{ 全壊 } & \multicolumn{2}{|c|}{ 半壊 } & \multicolumn{2}{|c|}{ 全壊 + 半壊 } \\
\hline & & & & 延長 $(\mathrm{m})$ & 延長比 $(\%)$ & 延長 $(\mathrm{m})$ & 延長比 $(\%)$ & 延長 (m) & 延長比 $(\%)$ \\
\hline \multirow{3}{*}{ 岩手 } & 堤防 & 78 & 13,919 & 3,214 & $23 \%$ & 2,342 & $17 \%$ & 5,557 & $40 \%$ \\
\hline & 護岸 & 106 & 11,063 & 225 & $2 \%$ & 243 & $2 \%$ & 468 & $4 \%$ \\
\hline & 胸壁 & 226 & 17,414 & 2,042 & $12 \%$ & 303 & $2 \%$ & 2,345 & $13 \%$ \\
\hline \multirow{3}{*}{ 宮城 } & 堤防 & 53 & 8,320 & 2,564 & $31 \%$ & 1,791 & $22 \%$ & 4,354 & $52 \%$ \\
\hline & 護岸 & 310 & 25,951 & 4,159 & $16 \%$ & 7,103 & $27 \%$ & 11,262 & $43 \%$ \\
\hline & 胸壁 & 98 & 9,548 & 1,858 & $19 \%$ & 410 & $4 \%$ & 2,268 & $24 \%$ \\
\hline \multirow{3}{*}{ 福島 } & 堤防 & 45 & 5,855 & 1,648 & $28 \%$ & 4,099 & $70 \%$ & 5,746 & $98 \%$ \\
\hline & 護岸 & 88 & 7,340 & 459 & $6 \%$ & 6,491 & $88 \%$ & 6,950 & $95 \%$ \\
\hline & 胸壁 & 0 & 0 & 0 & & 0 & 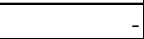 & 0 & \\
\hline \multirow{3}{*}{3 県計 } & 堤防 & 176 & 28,094 & 7,425 & $26 \%$ & 8,232 & $29 \%$ & 15,657 & $56 \%$ \\
\hline & 護岸 & 504 & 44,355 & 4,842 & $11 \%$ & 13,837 & $31 \%$ & 18,679 & $42 \%$ \\
\hline & 胸壁 & 324 & 26,963 & 3,900 & $14 \%$ & 713 & $3 \%$ & 4,613 & $17 \%$ \\
\hline
\end{tabular}

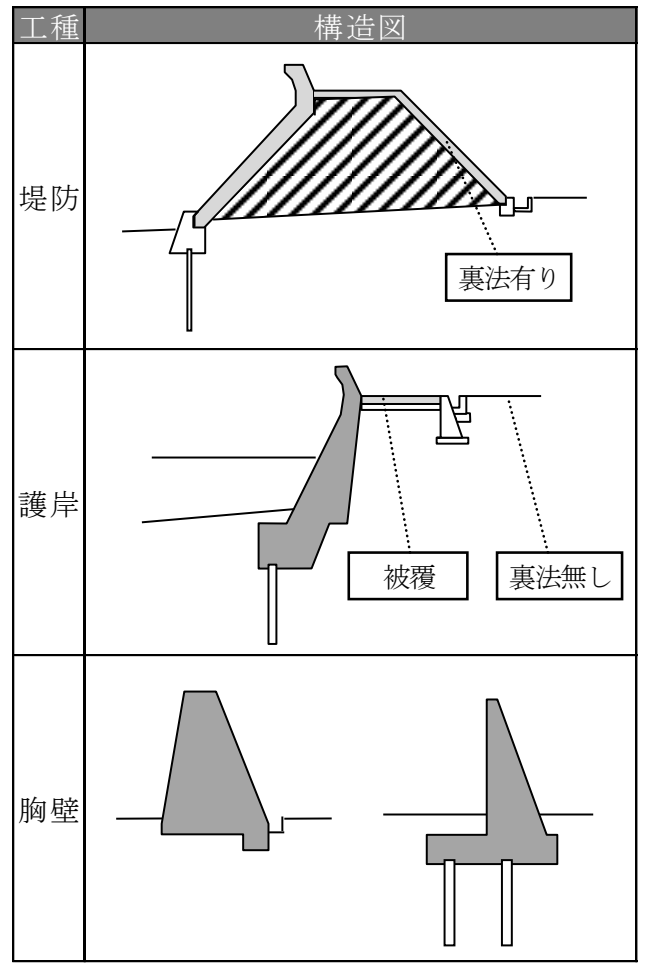

図-2 海岸保全施設（堤防・護岸・胸壁）の構造図
表-4 工種別被災パターン判定条件

\begin{tabular}{|c|c|c|c|}
\hline 工種 & 主要因 & 被災パターン & 判定条件 \\
\hline \multirow{5}{*}{ 堤防 } & \multirow{3}{*}{ 押し波 } & $\begin{array}{l}\text { 押し波による裏法尻 } \\
\text { の洗掘からの被災 }\end{array}$ & 施設の陸側での洗掘がある場合 \\
\hline & & \begin{tabular}{|l|} 
押し波による天端、 \\
裏法肩からの被災 \\
(裏法尻洗掘なし) \\
\end{tabular} & \begin{tabular}{|l} 
施設の陸側での洗掘がなく、かつ \\
天端被覆工・裏法被覆工での被害 \\
(流出、陥没など) があった場合
\end{tabular} \\
\hline & & \begin{tabular}{|l} 
押し波による波返工 \\
の破壊
\end{tabular} & $\begin{array}{l}\text { パラペットが陸側に倒壊している } \\
\text { 場合 }\end{array}$ \\
\hline & \multirow{2}{*}{ 引き波 } & \begin{tabular}{|l} 
引き波による表法尻 \\
の洗掘からの被災
\end{tabular} & 施設の海側での洗掘がある場合 \\
\hline & & \begin{tabular}{|l|} 
引き波による波返工 \\
の破壞
\end{tabular} & $\begin{array}{l}\text { パラペットが海側に倒壊している } \\
\text { 場合 }\end{array}$ \\
\hline \multirow{3}{*}{ 護岸 } & 押し波 & $\begin{array}{l}\text { 押し波による波返工 } \\
\text { の破壞 }\end{array}$ & $\begin{array}{l}\text { パラペットが陸側に倒壞している } \\
\text { 場合 }\end{array}$ \\
\hline & \multirow{2}{*}{ 引き波 } & \begin{tabular}{|l} 
引き波による表法尻 \\
の洗掘からの被災
\end{tabular} & 施設の海側での洗掘がある場合 \\
\hline & & \begin{tabular}{|l} 
引き波による波返工 \\
の破壞
\end{tabular} & $\begin{array}{l}\text { パラペットが海側に倒壞している } \\
\text { 場合 }\end{array}$ \\
\hline \multirow{4}{*}{ 胸壁 } & \multirow{2}{*}{ 押し波 } & $\begin{array}{l}\text { 押し波による堤体の } \\
\text { 転倒・滑動 }\end{array}$ & $\begin{array}{l}\text { 施設の陸側への倒壊・飛散がある } \\
\text { 場合 }\end{array}$ \\
\hline & & $\begin{array}{l}\text { 押し波による洗掘か } \\
\text { らの被災 }\end{array}$ & 施設陸側での洗掘がある場合 \\
\hline & \multirow{2}{*}{ 引き波 } & $\begin{array}{l}\text { 引き波による堤体の } \\
\text { 転倒・滑動 }\end{array}$ & $\begin{array}{l}\text { 施設の海側への倒壊・飛散がある } \\
\text { 場合 }\end{array}$ \\
\hline & & \begin{tabular}{|l} 
引き波による洗掘か \\
らの被災
\end{tabular} & 施設海側での洗掘がある場合 \\
\hline
\end{tabular}




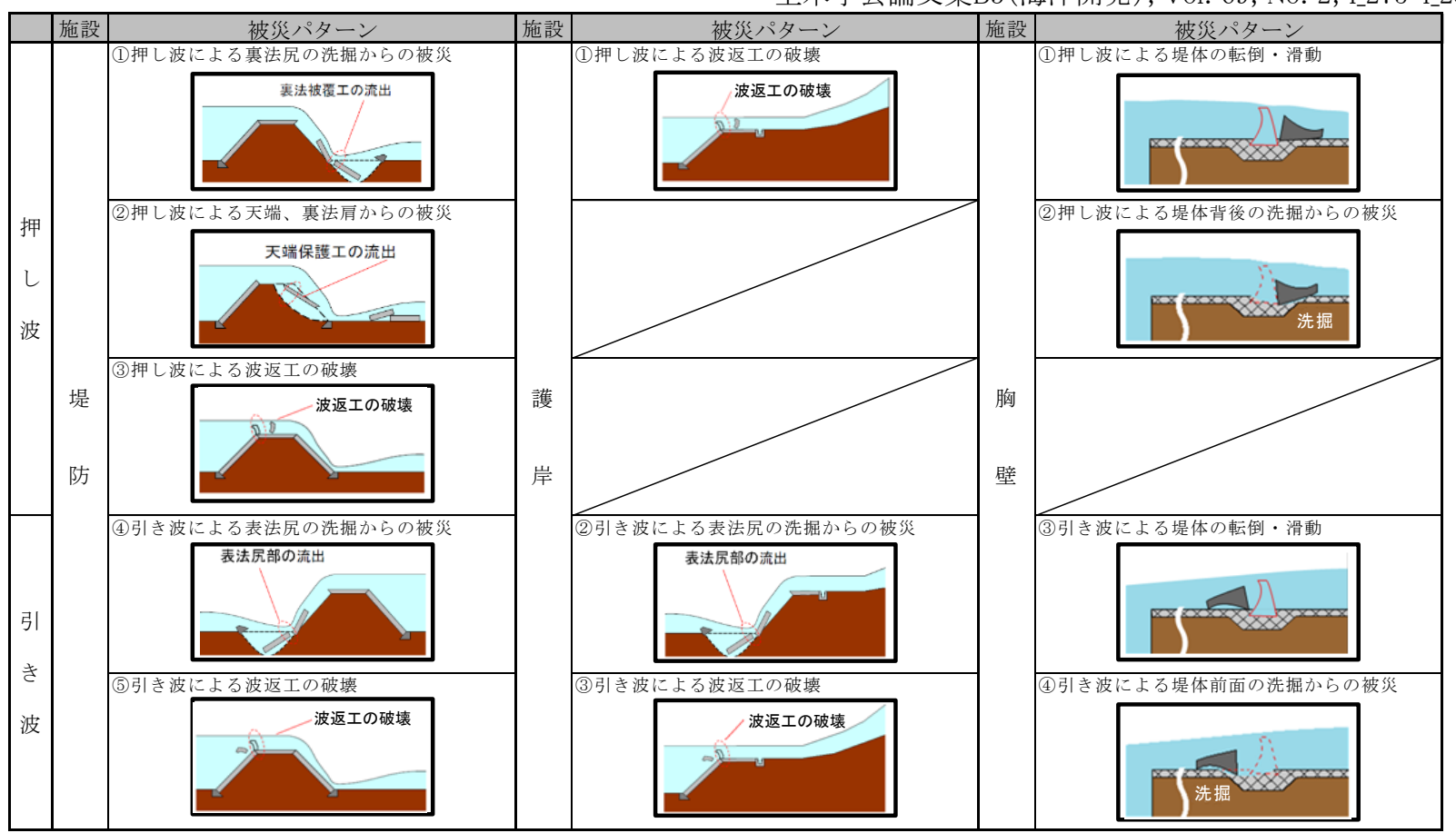

図-3 工種別被苂パターン分類

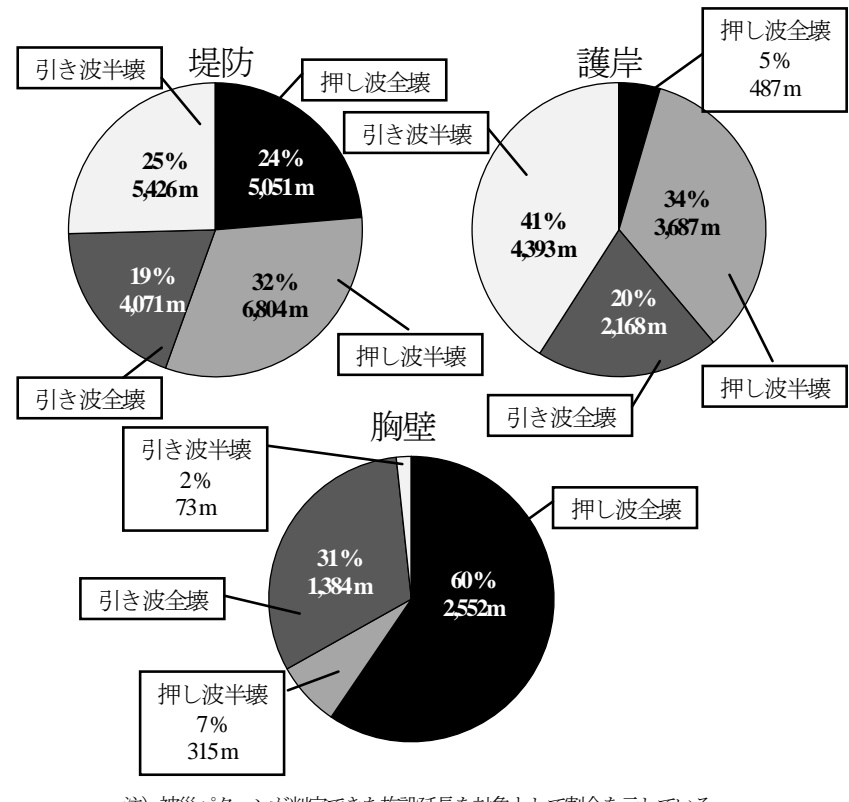

注）被災パターンが判定できた施設延長を対象として割合を示している。

図-4＼cjkstart施設工種別押し波，引き波による被災率割合

\section{5. 施設工種別の被災状況とその特徴}

被災パターンの整理結果として被災パターンが判定で きた施設を対象として，図-4に工種別に被災施設（全 壊，半壊）における押し波による被災と引き波による被 災の割合を示す．堤防が押し波11,855 m(56\%)，引き波 9,496 m(44\%)，護岸が押し波4,174 m(39\%)，引き波6,561 $\mathrm{m}(61 \%)$ ，胸壁が押し波 $2,867 \mathrm{~m}(67 \%)$ ，引き波 1,421 $\mathrm{m}(33 \%)$ であった．堤防は押し波と引き波による被災割 合が同程度であるが，護岸では引き波による割合が高く， 胸壁では押し波による割合が比較的高い.

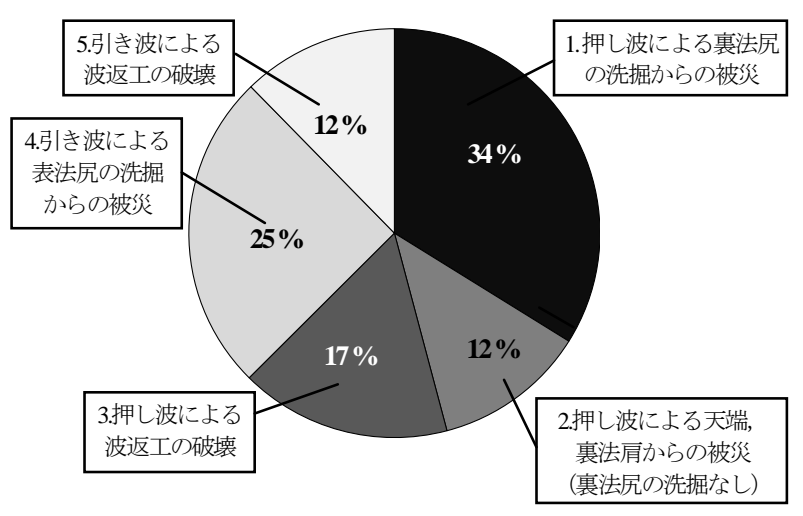

注）同一施設の複数の被災をカウントしているため、図- 4 と割合が異なる

図-5＼cjkstart堤防の被災パターン割合

\section{(1) 堤防}

図-5に堤防の被災パターンの分類結果を示す，堤防の 被災延長（全壊十半壊）において，押し波による裏法尻 の洗掘からの被災が34\%, 引き波による表法尻の洗掘か らの被災が25\%で，洗掘からの被災は計59\%，押し波に よる波返工の破壊が17\%，引き波による波返工の破壊は $12 \%$ で波返工の破壊は計 $29 \%$ であた。堤防では洗掘に 起因する被災が約6割と高くなっている．押し波による 洗掘が引き波による洗掘より割合が高いのは押し波と引 き波での流速・津波水位の違い，または施設前面と背後 での地盤条件の違い等が原因と考えられる.

\section{(2) 護岸}

図-6に護岸の被災パターンの分類結果を示す，護岸の 被災延長（全壊十半壊）において，引き波による表法尻 の洗掘からの被災が48％，押し波による波返工の破壊が $39 \%$ ，引き波による波返工の破壊は13\%であった．護岸 
では構造上引き波による被倓の割合が高くなるが，波返 工の破壊だけで比較すると押し波による破壊の割合が3 倍高く，津波来襲の段階で被災したと考えられる。

\section{(3) 胸壁}

図-7に胸壁の被災パターンの分類結果を示寸．胸壁の 全壊被災では，押し波による被災のうち，洗掘が確認さ れたものが68\%，確認できないものが32\%であった。引 き波による被災では，洗掘が確認されたものが92\%，確 認できないものが8 \%であった。押し波による被災のう ち，洗掘が生じていない延長が約3割あり，これらのケ 一スでは想定以上の津波力が作用し，洗掘が生じる前に 被災したものと推定される.

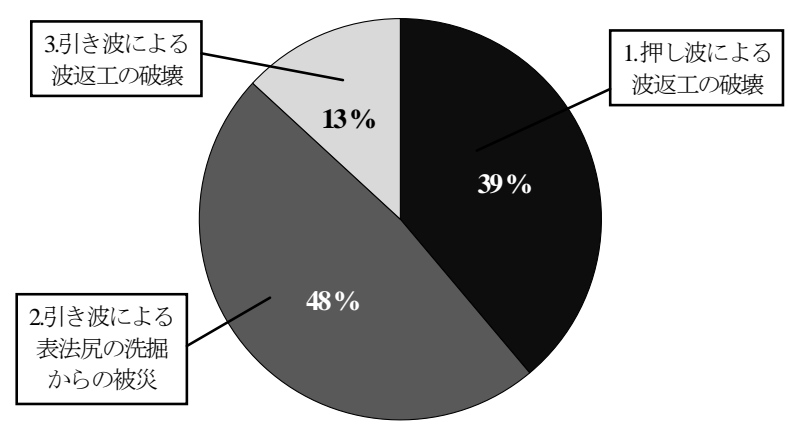

図-6 護岸の被苂パターン割合
また，押し波による洗掘は胸壁背後で生じているが， 引き波では堤前後の洗掘を伴っていることが多い.

\section{6. 工種別の越流深と被災状況}

被災状況・被災要因の傾向を把握することを目的とし，
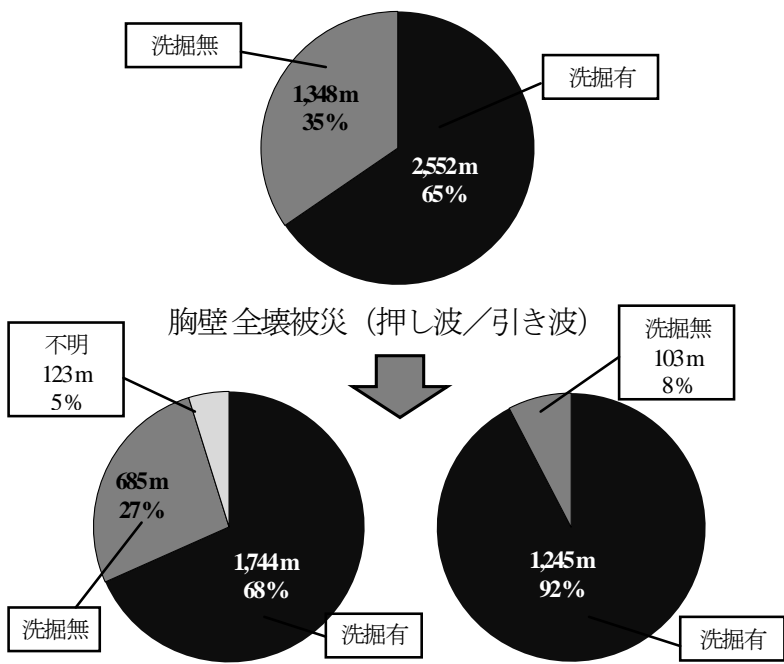

押し波による被災の 洗掘有無割合

引き波による被災の 洗掘有無割合

図-7＼cjkstart胸壁の被災パターン割合

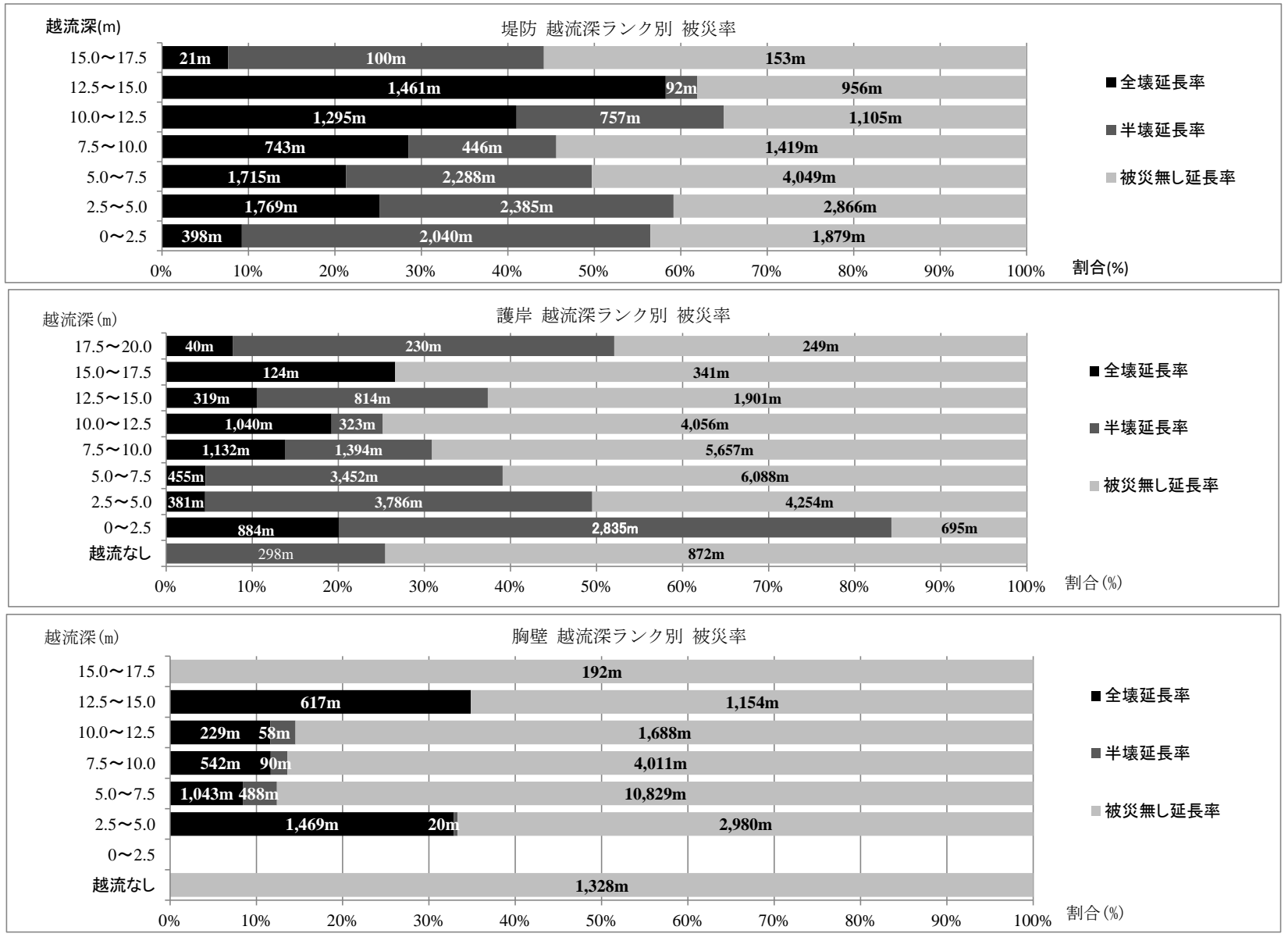

図-8工種別津波越流深と被災率の関係 
施設工種別に津波越流深と被災状況についての分析を行 った. 図-8に施設工種別の津波越流深と被災率の関係を グラフ化したものを示す。

被災延長率（全壊十半壊)は，越流深が大きくなるに 伴い，一度减少した後に再び高くなる傾向がある. 特に 護岸と胸壁においてその傾向が顕著である.

これらの結果から，越流時に堤上が射流となるような 場合，作用寸る流体力が大きくなって施設本体の破壊が 発生し，それよりも越流深が大きい場合には潜り越流あ るいは完全越流となり，施設に作用する流体力が小さく なって被災率が減少していることが推察される.

一方，越流深が極めて大きい場合にみられる被災率の 増加については, 越流深が大きくなると越流時に発生す る堤前後での落水および跳水現象の影響範囲が拡大し， 基礎が洗掘されることで被災に至るケースが多くなるた めと考えられ，法勾配が比較的緩やかな堤防と比心，護 岸・胸壁でその傾向が強くなっているものと思われる.

しかしながら，これらの現象は，津波水位の時間変化 や継続時間も被災機構に影響していることが考えられる ため, 数值シミュレーションや水理模型実験等による現 象の詳細な解明が今後の課題である.

\section{7. まとめ}

2011年東北地方太平洋沖地震における海岸保全施設に ついて堤防, 護岸, 胸壁の工種別に被災状況の把握と現 地踏査をもとにした被災パターンの分類・整理を行った。

被災状況では，胸壁は堤防，護岸と比較した場合，被 災時に全壊となる割合が高い，押し波と引き波による被
災の割合は，堤防では被災割合が同程度，護岸では引き 波による被災割合が高く，胸壁では押し波による被災割 合が高い.

堤防では洗掘に起因する被災が約6割で，押し波によ る被災の割合が高い. 護岸では引き波による被災の割合 が高いが，波返工の破壊だけで比較すると押し波による 破壊の割合が高い．胸壁では押し波による被災の場合， 洗掘が生じない例もあったが，引き波による被災ではほ とんどのケースで洗掘がみられた。津波越流深と被災率 の関係では, 越流深が大きくなるに伴い被災率が一度減 少した後に再び高くなる傾向があり，特に護岸と胸壁に おいてその傾向が顕著であった.

なお，「平成23年度海岸保全施設設計条件等緊急調 查」では, 本報で述べた調査結果に加え, 数值シミュレ ーションや水理模型実験を実施し, 津波来襲時に海岸保 全施設に加わる外力等を検証するとともに，今後，海岸 保全施設を津波に対して粘り強い構造とするための方策 として，以下のような提言を行っている.

・天端被覆工と表／裏法面被覆工の一体化

・越流時の水圧に耐えるために天端被覆工の強化

・裏法尻保護工の設置

・越流流速を抑制するための裏法の緩勾配化

・引き波による前面地盤の洗掘対策強化

・胸壁の越流時の洗掘対策強化

・引き波流速に安定な重量の基礎被覆ブロックの使用

\section{参考文献}

1) 東北地方太平洋沖地震津波合同調查グループ: 統一 データセット release 20120301,

http://www.coastal.jp/ttjt/

\title{
THE DAMAGE OF SHORE PROTECTION FACILITIES AROUND THE FISHING PORT DUE TO THE 2011 OFF THE PACIFIC COAST OF TOHOKU EARTHQUAKE AND TSUNAMI
}

\author{
Noritaka ASAKAWA, Takashi NAKAMURA, Hiroyuki KATO, \\ Hikaru HAYAKAWA, Katsuhiro SATO, Toshifumi MIKAMI, \\ Atsushi KODAMA and Akira SUZUKI
}

The coastal areas of Tohoku was atacced by Tsunami due to the 2011 Off The Pacific Coast of Tohoku Earthquake that occurred on March 11, 2011.There were severe damage to shore protection facilities, dikes, seawalls, and breast wall. Because it was assumed that the tsunami was higher than the external force of the shore protection facilities design, Fisheries Agency conducted the survey of the disaster, the analysis of the external force and a review of the design conditions before the restraction works.

In this paper, we reducted the situation of damage to facilities and the patterns affected from the results of the "The 2011 emergency survey of the disign conditions of shore protection facilities".Breast wall affected is higher than the percentage of destroyed dikes and seawall.Percentage of affected by the push waves and back waves, the damage of dikes were about the same, the damage of seawall were a high percentage by back wave, and the damage of breast wall were a high percentage by push waves. 